\title{
Experimental Study of Wind Turbine blade consists of Airfoils (NACA 63.XXX+FFA-W3)
}

Tarek Abdel Malak Mekhaila, Mohamed Fathy Cidek $^{\mathrm{a}}$, Hesham Sayed Abdel-Mohsen ${ }^{\mathrm{a}}$ and *Ahmed Salah Mousa ${ }^{b}$

\author{
${ }^{a}$ Mech. Eng. Dept., Aswan Faculty of Ene. Engineering, Aswan University, Aswan, Egypt \\ bNew and Renewable Energy Authority
}

Abstract-Wind turbines have been shown to be one of the most viable sources of renewable energy. With new technology, the low cost of wind energy is competitive with more conventional sources of energy such as coal. Most blades available for commercial grade wind turbines incorporate a straight span-wise profile and airfoil shaped cross sections. In this paper studies of NACA 63.XXX+FFAW3 airfoils blade at zafarana wind farm, Egypt. The Wind turbine's structure, parameters, electrical control system and low voltage installation are introduced; there are two projects at Zafarana site are focused. The first is named as zafarana No. (7) Consists of $\mathbf{1 4 2}$ turbines as shown figure (1-a) and the other is named as zafarana No. (8) Consists of 142 turbines as shown figure. (1-b), the distance between them is about $\mathbf{1 2}$ kilometers. This paper studies the effect of wind speed, landscape, alarms and spare parts on the power production and availability

Keywords-: wind turbine, power generation, availability, wind speed

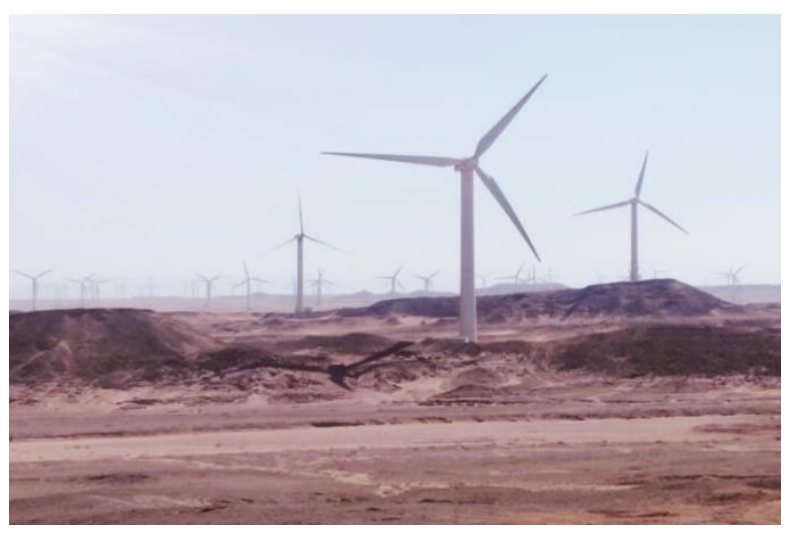

Fig. 1-a

\section{INTRODUCTION}

Wind turbines interact with the wind, capturing part of its kinetic energy and converting it into usable energy. Historic designs, typically large, heavy and inefficient, were replaced in the 19th century by fossil fuel engines and the implementation of a nationally distributed power network. A greater understanding of aerodynamics and advances in materials, particularly polymers, has led to the return of wind energy extraction in the latter half of the 20th century. Wind power devices are now used to produce electricity, and commonly termed wind turbines. This paper mainly introduces studying two projects in zafarana site and the affection of climate, landscape, human factors, mitigations loads "depend on national network of electricity " and spare parts.

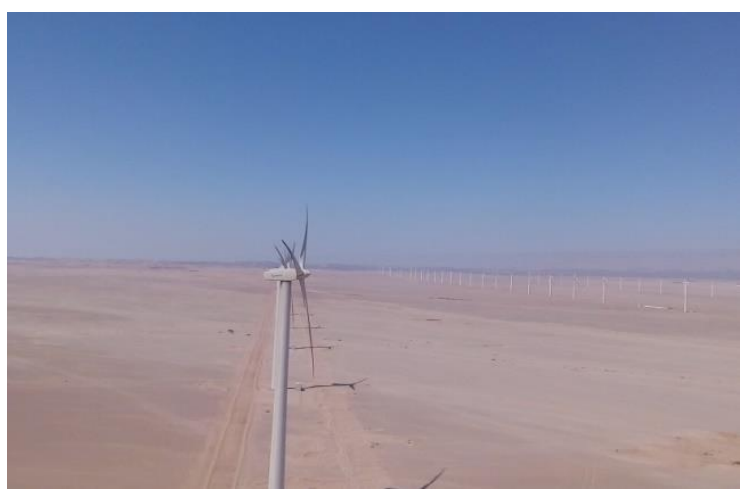

Fig. 1-b

Fig. 1-a, 1-b the landscape zafarana NO. (8) is flatter than zafarana NO.(7) 


\section{WINDTURBINE DESCRIPTION}

The Gamesa G52- 850 kW is a three bladed, upwind, pitch regulated and active yaw upwind-turbines as shown figure 2-a It has a rotor diameter of $52 \mathrm{~m}$ as shown figure 2-b and uses the Ingecon- $W$ control system concept that enables the wind-turbine to operate in a broad range of variation of rotor speed [1]. The rotor pitch is variable and equipped with Optitip system. This feature provides fine adjustment of the blade-operating angle at all times with respect to power production and noise emission.

The main shaft transmits the power to the generator through the gearbox. The gearbox is a 3 stages Combined planetary and helical parallel shafts gearbox. From it the power is transmitted via a flexible coupling to the generator.

The generator is a high efficiency 4 - pole doubly fed generator with wound rotor and slip rings.

The wind-turbine primary brake is given by full feathering the blades. The redundant brake is an emergency disc brake system hydraulically activated and mounted on the gearbox high-speed shaft.

All functions of the wind turbine are monitored Vange) controlled by several microprocessor based control units. The controller system is placed in the nacelle. Blade pitch angle variation is regulated by a hydraulic system actuator which enables the blade to rotate from $-5^{\circ}$ to $88^{\circ}$. This system also supplies pressure to the brake system.

The yaw system consists of two gears electrically operated and controlled by the wind turbine controller based on information received from the wind vane mounted on top of the nacelle. The yaw gears rotate the yaw pinions, which mesh with a large toothed yaw ring mounted on the top of the tower. The yaw bearing is a plain bearing system with built-in friction.

\section{A- INGECON-W SYSTEM}

The Ingecon-W system consists of an effective asynchronous generator with wound rotor, slip rings, and two 4-quadrant converters with IGBT switches, contactors and protection [2]

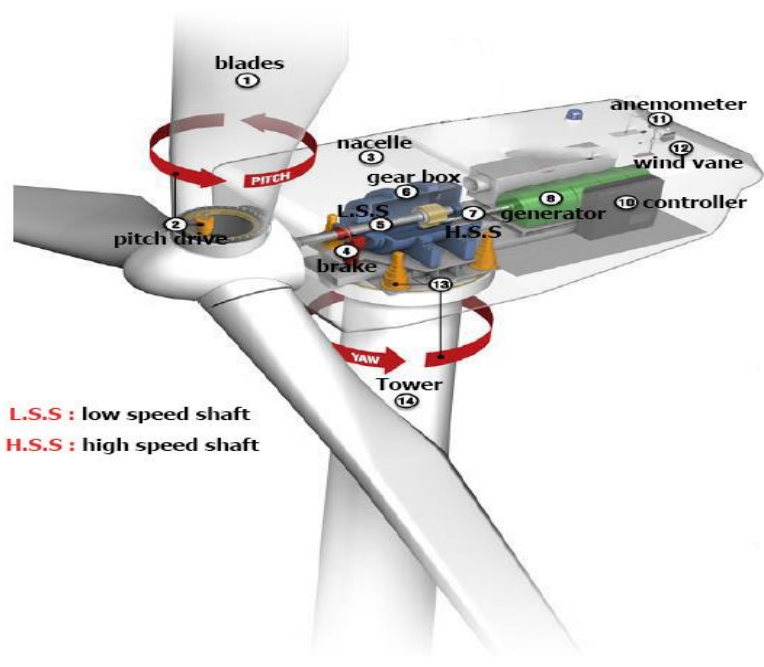

Fig. 2-a

\section{B- MEASURING THE WIND}

Outside the nacelle, in the rear part, a vertical mast supports the wind-measuring sensors (anemometer and wind-vane).

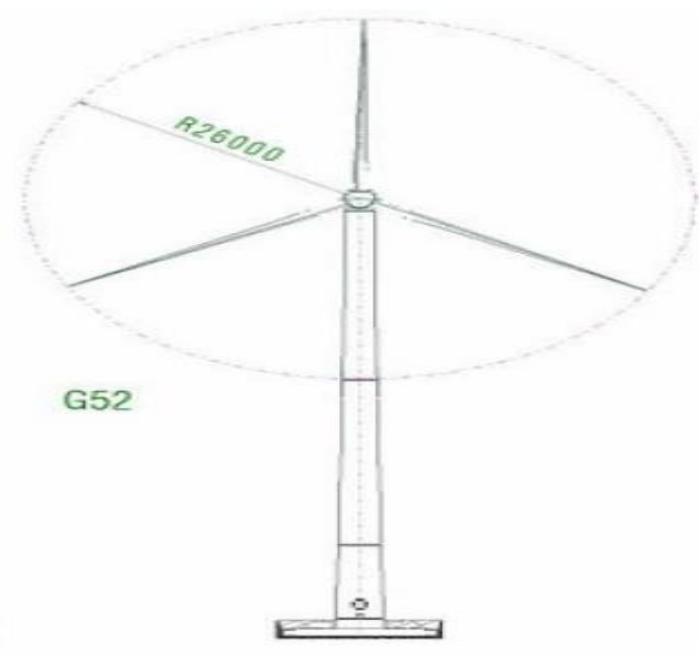




\section{C- DESCRIPTION OF THE DOUBLE FED SYSTEM}

The double fed machine (DFM) is the equipment that regulates and protects electrical energy production from the wind turbine. The double fed machine consists of a double fed asynchronous generator with access to the rotor winding via slip rings. The stator (in delta) is connected directly to the grid and the rotor is connected to a frequency converter[3]. In addition, the converter is connected to the grid. This layout ensures that, for electrical distribution grid, the wind turbine behaves as a synchronous generator. Which serves to stabilize the grid, enabling the connection of several wind turbines, and eliminates the need for capacitor banks to compensate reactive power and resonance problems, The converter control unit (CCU) controls the active and reactive power with the frequency converter connected to the generator rotor, this is, and it allows the user to select the desired power factor.

The single row-diagram the double fed machine is as following

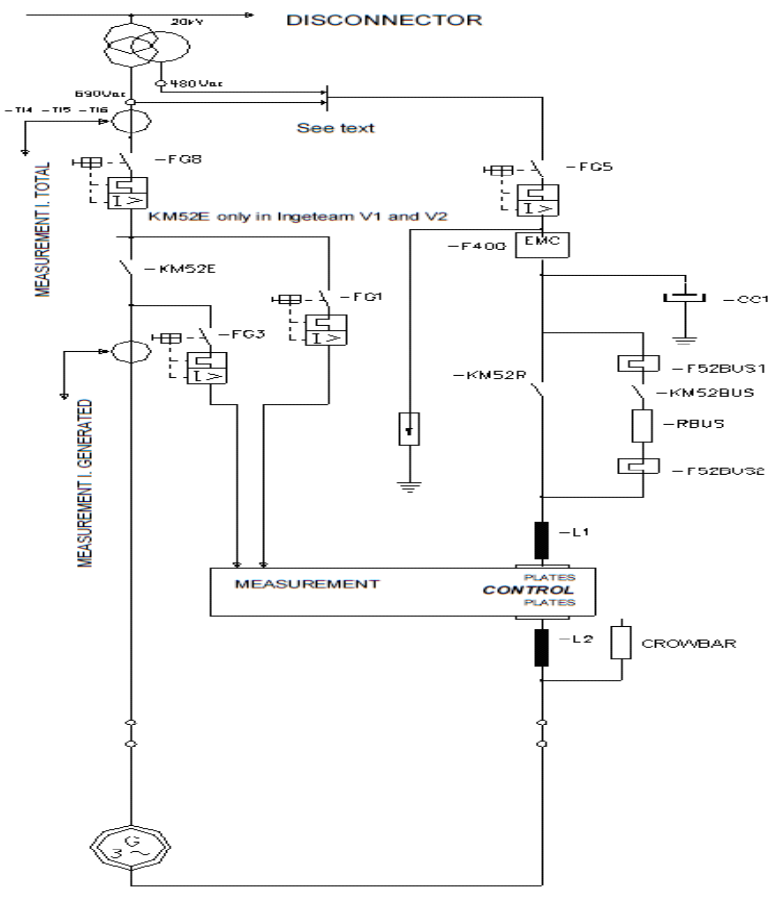

The main characteristics of the LV installation are listed below.

- Rated voltage

$690 \mathrm{~V}$

- Frequency $50 / 60 \mathrm{HZ}$

- Rated power $850 \mathrm{KW}$

- Rated current a t690V

$800 \mathrm{~A}$

- Maximum short- circuit current in LV (MV grid+generator)

$16 \mathrm{~A}$

- Rated current provided by a wind turbine at $20 \mathrm{KV}$

$27.6 \mathrm{~A}$

- Rated current provided by a wind turbine at $30 \mathrm{KV}$

$18.4 \mathrm{~A}$

Generator data

- Voltage per phase

$690 \mathrm{~V}$

- Resistance of stator"R1"

$0.0159(115 \mathrm{C})$

- Reactance of stator"X1"

- Resistance of the rotor referred to stator "R2"

$0.011 \Omega$

- Reactance of the rotor referred to stator "X2"

$0.105 \Omega$

Tables 1. Parameters of the design of G52 - 850 KW wind-turbines [4]

\begin{tabular}{|c|c|c|c|}
\hline Concept & Value & Units & Remarks \\
\hline IEC class & $\mathbf{S}$ & - & $\begin{array}{l}\text { IEC 61400- } \\
\text { Ed.2 }\end{array}$ \\
\hline Annual mean wind speed & 7.5 & $\mathbf{m} / \mathbf{s}$ & $\begin{array}{l}\text { Referred to } \\
\text { hub height }\end{array}$ \\
\hline $\begin{array}{l}\text { Weibull shape parameter } \\
\text {,K }\end{array}$ & 2 & - & \\
\hline $\begin{array}{l}\text { Turbulence intensity at } \\
15 \mathrm{~m} / \mathrm{s}, \mathrm{I}_{16}\end{array}$ & 16 & $\%$ & \\
\hline $\begin{array}{l}\text { Reference wind } 10 \mathrm{~min} \text {. } \\
\text { averaged }\end{array}$ & 43 & $\mathbf{m} / \mathbf{s}$ & $\begin{array}{l}50 \text { years } \\
\text { recurrence } \\
\text { time }\end{array}$ \\
\hline $\begin{array}{l}\text { Reference wind } 3 \text { sec. } \\
\text { averaged }\end{array}$ & 52.5 & $\mathbf{m} / \mathbf{s}$ & $\begin{array}{l}\text { 50 years } \\
\text { recurrence } \\
\text { time }\end{array}$ \\
\hline Stop / restart wind speed & 21/18 & $\mathbf{m} / \mathbf{s}$ & 100 sec filtere \\
\hline
\end{tabular}


NOCE CONE

\begin{tabular}{|c|c|}
\hline DEMENSIONS & $\begin{array}{c}\text { Length } 2.70 \mathrm{~m} \text {; root } \\
\text { Diameter } 2.20 \mathrm{~m}\end{array}$ \\
\hline MATERIAL & $\begin{array}{c}\text { Glass reinforced polyester } \\
\text { coated with gel- coat }\end{array}$ \\
\hline WEIGHTS & $220 \mathrm{Kg}$ \\
\hline
\end{tabular}

BLADE

\begin{tabular}{|c|c|}
\hline Principle & $\begin{array}{c}\text { Shells bonded to supporting } \\
\text { beam }\end{array}$ \\
\hline Material & Glass fibre reinforced epoxy \\
\hline Blade connection & Steel root inserts \\
\hline Airfoils & NACA 63.XXX+FFA-W3 \\
\hline Length & $\mathbf{2 5 . 3 m}$ \\
\hline Chord(root/tip) & $\mathbf{2 . 3 2 m / 0 . 3 m}$ \\
\hline Max. Twist & $\mathbf{1 6 . 4}^{\mathbf{0}}$ \\
\hline Weight & Approx.2550 Kg/piece \\
\hline
\end{tabular}

\section{ROTOR}

\begin{tabular}{|c|c|}
\hline Diameter & $52 \mathrm{~m}$ \\
\hline Swept Area & $\mathbf{2 0 1 0 . 9} \mathbf{~ m}^{\mathbf{2}}$ \\
\hline Rotational Speed \\
Operation Interval & $14.6: 30.8 \mathrm{rpm}(\mathrm{T55}, \mathbf{T 6 5 m})$ \\
& $16.2: 30.8 \mathrm{rpm}(\mathrm{T44m})$ \\
\hline Sense of Rotation & Clockwise (front view) \\
\hline Rotor Orientation & Upwind \\
\hline Tilt angle & $\mathbf{6}^{\mathbf{0}}$ \\
\hline Blade coning & $\mathbf{3}^{\mathbf{0}}$ \\
\hline Number of blades & 3 \\
\hline Aero-dynamic brake & Full feathering \\
\hline
\end{tabular}

\begin{tabular}{|c|c|}
\hline \multicolumn{2}{|c|}{ NACELLE COVER } \\
\begin{tabular}{|c|c|}
\hline $6590 \times 2240 \times 2850 \mathrm{~mm}^{3}$ & Dimensions \\
\hline $\begin{array}{c}\text { Glass fibre and polyester } \\
\text { resin }\end{array}$ & Material \\
\hline $1600 \mathrm{Kg}$ & Weight \\
\hline
\end{tabular}
\end{tabular}

\section{ROTOR HUP}

\begin{tabular}{|c|c|}
\hline Spherical & Type \\
\hline Nodular Cast Iron & Material \\
\hline $\begin{array}{c}\text { EN-GJS-400-18U-LT } \\
\text { per EN 1563 }\end{array}$ & Material specification \\
\hline
\end{tabular}

\section{MAIN SHAFT SUPPORT}

\begin{tabular}{|l|l|}
\hline Type & Cast iron support \\
\hline Material & Nodular cast iron \\
\hline Material speciation & $\begin{array}{l}\text { EN-GJS-400-18U-LT Per EN } \\
1563\end{array}$ \\
\hline
\end{tabular}

MAIN SHAFT BEARING

\begin{tabular}{|c|c|}
\hline Type & Spherical Bearings \\
\hline \multicolumn{2}{|l|}{ Blade bearing } \\
\hline Type & $\begin{array}{l}\text { 4- Point ball bearing. Double } \\
\text { row }\end{array}$ \\
\hline \multicolumn{2}{|c|}{ MAIN SHAFT } \\
\hline Type & Forged shaft \\
\hline material & Quenched and tempered steel \\
\hline Material speciation & 34CrNiMo6 per EN 10083-1 \\
\hline \multicolumn{2}{|c|}{ YAW GEARS } \\
\hline \multirow[t]{2}{*}{ Type } & 3planetary stages \\
\hline & $\begin{array}{l}1 \text { worm gear non- locking } \\
\text { Stage (maximum ratio 1:10) }\end{array}$ \\
\hline motor & $\begin{array}{l}2.2 \mathrm{~kW} .6 \text { pole } \\
\text { Asynchronous motor with } \\
\text { brake }\end{array}$ \\
\hline \multicolumn{2}{|c|}{ MAIN FRAME } \\
\hline Type & $\begin{array}{l}\text { Combination of welded steel } \\
\text { plates }\end{array}$ \\
\hline \multicolumn{2}{|c|}{ YAW SYSTEM } \\
\hline Type & $\begin{array}{l}\text { Plain bearing system with } \\
\text { brakes and spring } \\
\text { Loaded pads }\end{array}$ \\
\hline \multicolumn{2}{|c|}{ material } \\
\hline \multicolumn{2}{|l|}{ Yaw ring } \\
\hline Base & $\begin{array}{l}\text { EN-GJS-400-18U-LT ass.to } \\
\text { EN } 1563\end{array}$ \\
\hline Teeth inserts & 42 CrMo4 per EN 10083 \\
\hline Plain bearing & PETP \\
\hline Yaw speed & $0.4^{0} / \mathrm{s}: 1$ turn each $15 \mathrm{~min}$ \\
\hline
\end{tabular}

\section{TOWER SECTION CHARACTERISTIC}

\begin{tabular}{|l|l|l|l|l|}
\hline & $\begin{array}{l}\text { Length } \\
{[\mathrm{mm}]}\end{array}$ & $\begin{array}{l}\text { Outer } \emptyset \text { at } \\
\text { Bottom }[\mathrm{mm}]\end{array}$ & $\begin{array}{l}\text { Outer } \emptyset \text { at } \\
\text { top }[\mathrm{mm}]\end{array}$ & $\begin{array}{l}\text { Weight } \\
{[\mathrm{Kg}]}\end{array}$ \\
\hline Tower44 & \multicolumn{5}{|l|}{} \\
\hline Bottom & $\mathbf{1 7 6 8 8}$ & $\mathbf{3 0 1 8}$ & $\mathbf{2 4 4 0}$ & $\mathbf{2 2 0 0 0}$ \\
\hline Top & $\mathbf{2 4 4 4 8}$ & $\mathbf{2 4 4 0}$ & $\mathbf{2 1 7 0}$ & $\mathbf{1 8 1 0 0}$ \\
\hline Tower 55m & \multicolumn{5}{|l}{} \\
\hline Bottom & $\mathbf{9 6 1 0}$ & $\mathbf{3 3 2 0}$ & $\mathbf{3 0 2 6}$ & $\mathbf{1 6 2 0 0}$ \\
\hline Top & $\mathbf{1 9 1 8 5}$ & $\mathbf{3 0 2 6}$ & $\mathbf{2 4 4 0}$ & $\mathbf{2 2 5 0 0}$ \\
\hline intermediate & $\mathbf{2 4 4 4 8}$ & $\mathbf{2 4 4 0}$ & $\mathbf{2 1 7 0}$ & $\mathbf{1 8 1 0 0}$ \\
\hline
\end{tabular}


III .Case study of wind turbine blade consists of profiles (NACA63.xxx+FFA-W3), model G5 $r$

Table 2. Comparison between two project at Zafarana wind farm, Egypt through years 2017, 2018, 2019

\begin{tabular}{|l|l|l|}
\hline name & Zafarana No.(8) & Zafarana No.(7) \\
\hline No. of turbines & 142 & 142 \\
\hline Turbine model & G52 & G52 \\
\hline $\begin{array}{l}\text { Rated power(per a } \\
\text { turbine) }\end{array}$ & $850 \mathrm{KW}$ & $\mathbf{8 5 0} \mathrm{KW}$ \\
\hline Manufacturer & Gamesa & Gamesa \\
\hline Total power & $120 \mathrm{MW}$ & $120 \mathrm{MW}$ \\
\hline Blade airfoils & $\begin{array}{l}\text { NACA } \\
\text { 63.XXX+FFA- }\end{array}$ & $\begin{array}{l}\text { NACA } \\
\text { 63.XXX+FFA- } \\
\text { W3 }\end{array}$ \\
\hline
\end{tabular}

The affection of the wind and landscape on power production and availability through years 2017, 2018, 2019 as shown at the following figures and tables.

\section{Some notes:-}

A- The distance between the two projects is about 12 kilometers

B- The landscape of project Zafarana No.(7) is worse than the landscape of project Zafarana No.(8) as shown figure(1-a), (1-b)

\section{IV .RESULTS AND DISCUSSION}

Figures[3,4,5] show power generation distribution of project Zafarana NO.(8) and project Zafarana No.(7) through years $2017,2018,2019$ respectively where year 2019 is from (Jan to Sep), and show the effect of wind speed, landscape and availability on the power generated from the two projects. as shown the power increases with the wind speed

Generally, the power generated from Zafarana No. (8) is larger than from Zafarana No. (7) Because of :

1- The wind speed in Zafarana No. (8) Is higher than in Zafarana No. (7)

2- The landscape of Zafarana No. (8) Is flatter than Zafarana No. (7)

3- Efficient manpower plays main role in the power generation

Figures [6], [7] show the power distribution of the two projects in June and December. At Year 2017 the maximum power was occurred in June and the minimum power was occurred in December at the two projects.

Figures [8,9] show the power distribution of the two projects in September and November.

At Year 2018 the maximum power was occurred in September and minimum power was occurred in November at the two projects.

As the years pass, the wind speed decreases gradually where the average wind speed at 2019 was smaller than at 2018, and the average wind speed at 2018 was smaller than at 2017 in zafarana site.

Table 3. annual power distribution of the two projects in 2017

\begin{tabular}{|c|c|c|c|c|c|c|}
\hline \multirow[t]{2}{*}{ months } & \multicolumn{3}{|c|}{ Zafarana NO.(8) } & \multicolumn{3}{|c|}{ Zafarana NO.(7) } \\
\hline & Power(MWh & Wind(m/s) & availability & Power(MWh) & $\operatorname{Wind}(\mathbf{m} / \mathbf{s})$ & availability \\
\hline Jan & 19407 & 6.7 & $89.8 \%$ & 18846 & 5.8 & $73.4 \%$ \\
\hline Feb & 19042 & 5.6 & $93.3 \%$ & 16219 & 6 & $76.1 \%$ \\
\hline mar & 21190 & 6.8 & $93 \%$ & 17161 & 6.1 & $\mathbf{7 4 . 8 \%}$ \\
\hline apr & 21784 & 6.9 & $84 \%$ & 20956 & 6.2 & $73.6 \%$ \\
\hline may & $\overline{17022}$ & 6.8 & $76.9 \%$ & $\mathbf{1 5 7 8 9}$ & 6.5 & $76.6 \%$ \\
\hline Jun & 25995 & 7.4 & $68.1 \%$ & 20882 & 6.4 & $57.3 \%$ \\
\hline jul & 21212 & 7.3 & $68 \%$ & 17714 & 6.6 & $60.1 \%$ \\
\hline Aug & 21399 & 7.5 & $67.6 \%$ & 16517 & 6.5 & $63.5 \%$ \\
\hline sep & 16799 & 8.5 & $64.7 \%$ & 18186 & 8.2 & $55.1 \%$ \\
\hline oct & 17615 & 7.2 & $73 \%$ & 13325 & 6.5 & $55.6 \%$ \\
\hline nov & 15303 & 4.9 & $81.3 \%$ & 13839 & 6.1 & $62.9 \%$ \\
\hline Dec & 9790 & 5.6 & $81.7 \%$ & 9499 & 5.5 & $66.4 \%$ \\
\hline
\end{tabular}




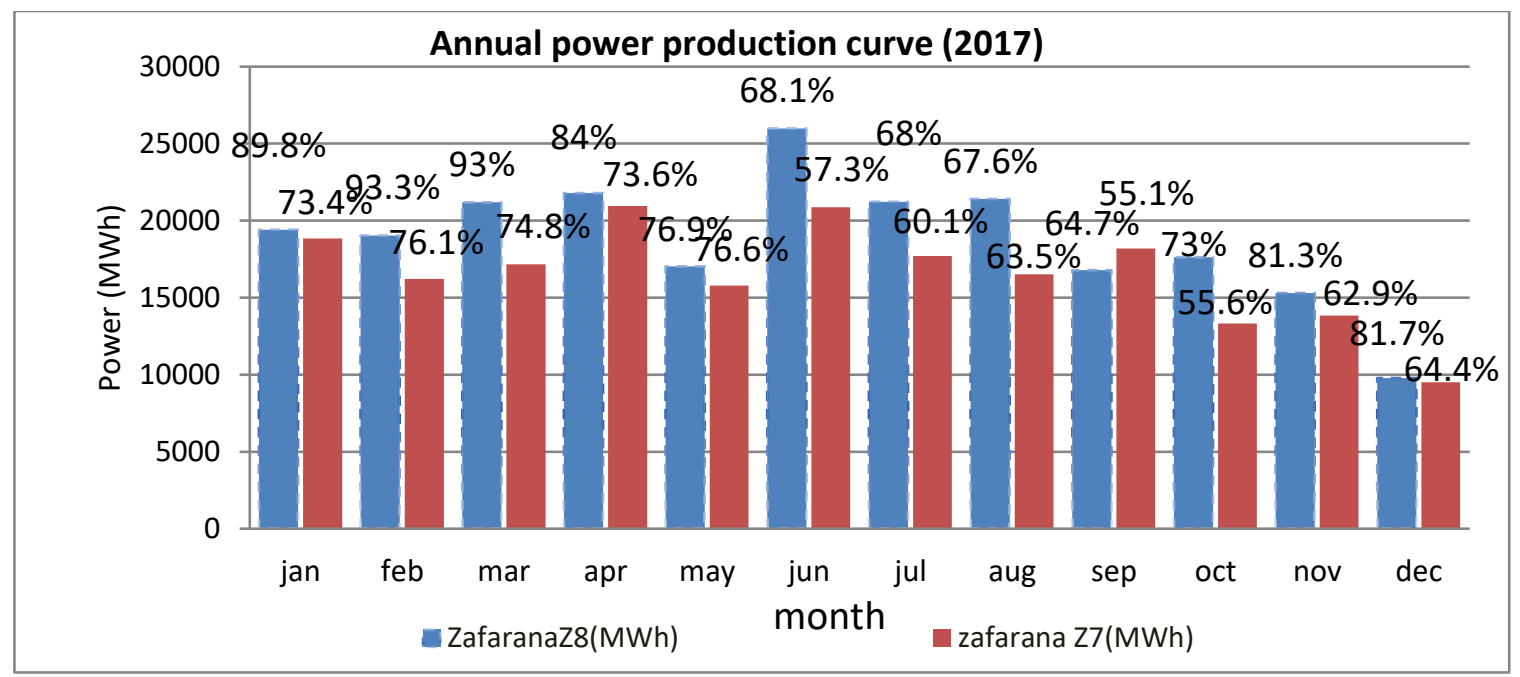

Fig. 3 Annual power distribution of the two projects in 2017

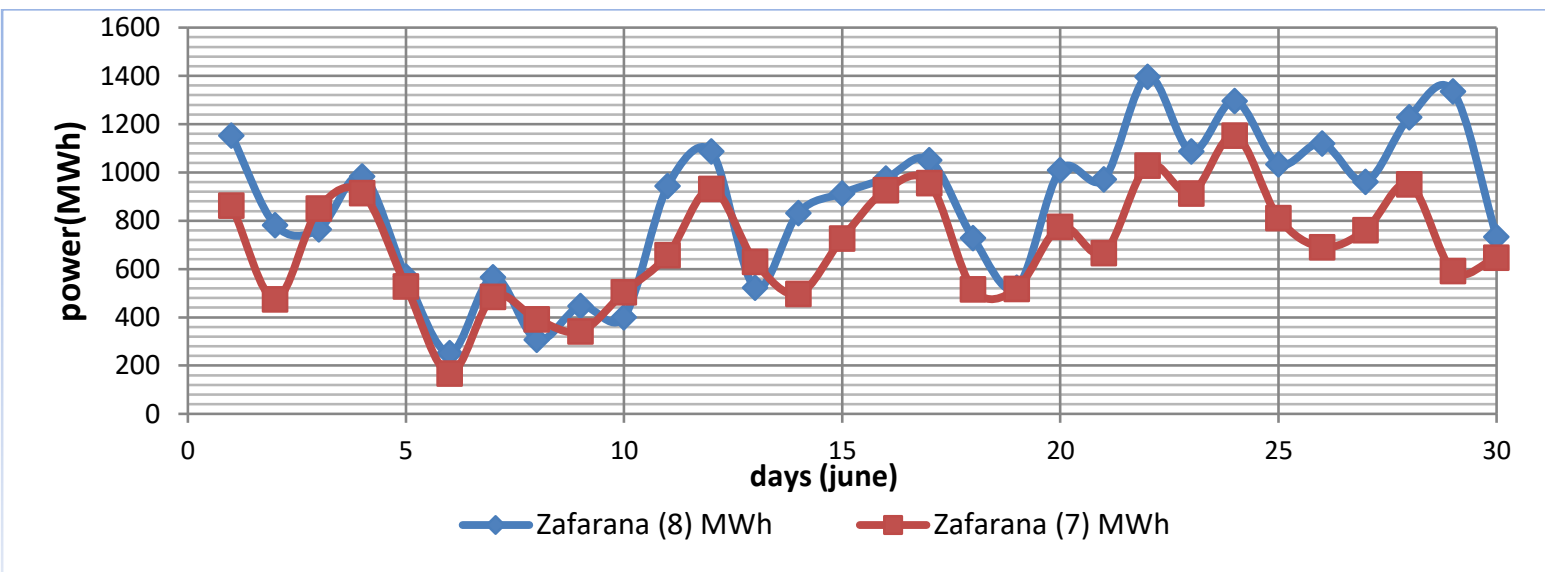

Fig. 6 Power distribution of the two projects in June (2017)

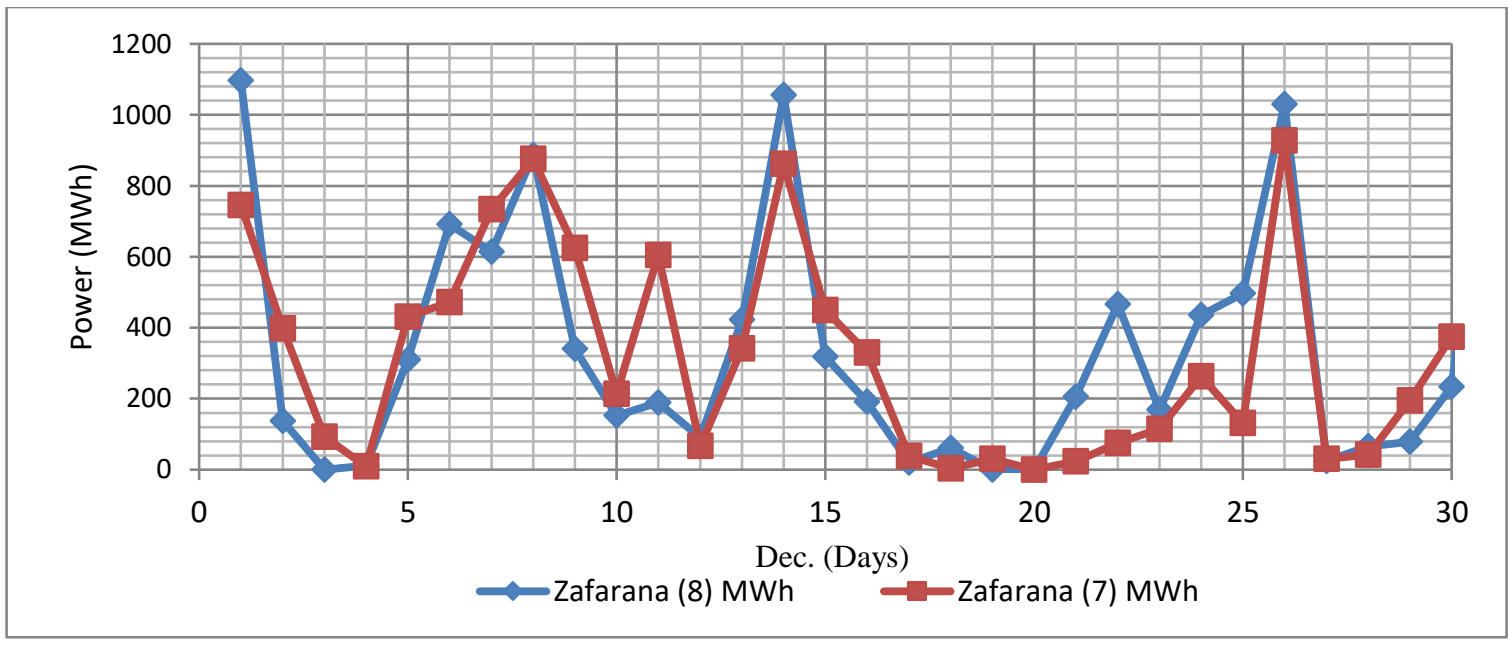

Fig. 7 Power distribution of the two projects in Dec. (2017) 
Table 4. Annual power distribution of the two projects in 2018

\begin{tabular}{|c|c|c|c|c|c|c|}
\hline \multirow[t]{2}{*}{ months } & \multicolumn{3}{|c|}{ Zafarana NO.(8) } & \multicolumn{3}{|c|}{ Zafarana NO.(7) } \\
\hline & Power(MWh) & Wind $(\mathbf{m} / \mathbf{s})$ & availability & Power(MWh) & Wind $(\mathrm{m} / \mathrm{s})$ & availability \\
\hline Jan & 17060 & 6.1 & $86.7 \%$ & 13686 & 6.1 & 70.2 \\
\hline feb & 12399 & 6.2 & $90.4 \%$ & 11222 & 6 & $72.5 \%$ \\
\hline mar & 20834 & 6.5 & $90.8 \%$ & 17909 & 6.1 & 76.9\% \\
\hline apr & 24760 & 6.9 & $91.4 \%$ & 22403 & 6.2 & $79 \%$ \\
\hline may & 25063 & 6.8 & $90.1 \%$ & 22431 & 6.7 & $81.6 \%$ \\
\hline Jun & 28245 & 7.3 & $89.9 \%$ & 22616 & 7 & $79.9 \%$ \\
\hline jul & 25947 & 7.2 & $89.8 \%$ & 22085 & 7.2 & $81.7 \%$ \\
\hline Aug & 32312 & 6.9 & $91.1 \%$ & 28297 & 6.5 & $81.1 \%$ \\
\hline sep & 33896 & 8.4 & $91 \%$ & 30962 & 8.1 & $80.4 \%$ \\
\hline oct & 22716 & 6.5 & $89.9 \%$ & 22004 & 6 & $80.4 \%$ \\
\hline nov & 8803 & 6.3 & $89.8 \%$ & 9996 & 5.8 & $93.10 \%$ \\
\hline Dec & 14635 & 5.3 & $87.5 \%$ & 12564 & 5.1 & $88.2 \%$ \\
\hline
\end{tabular}

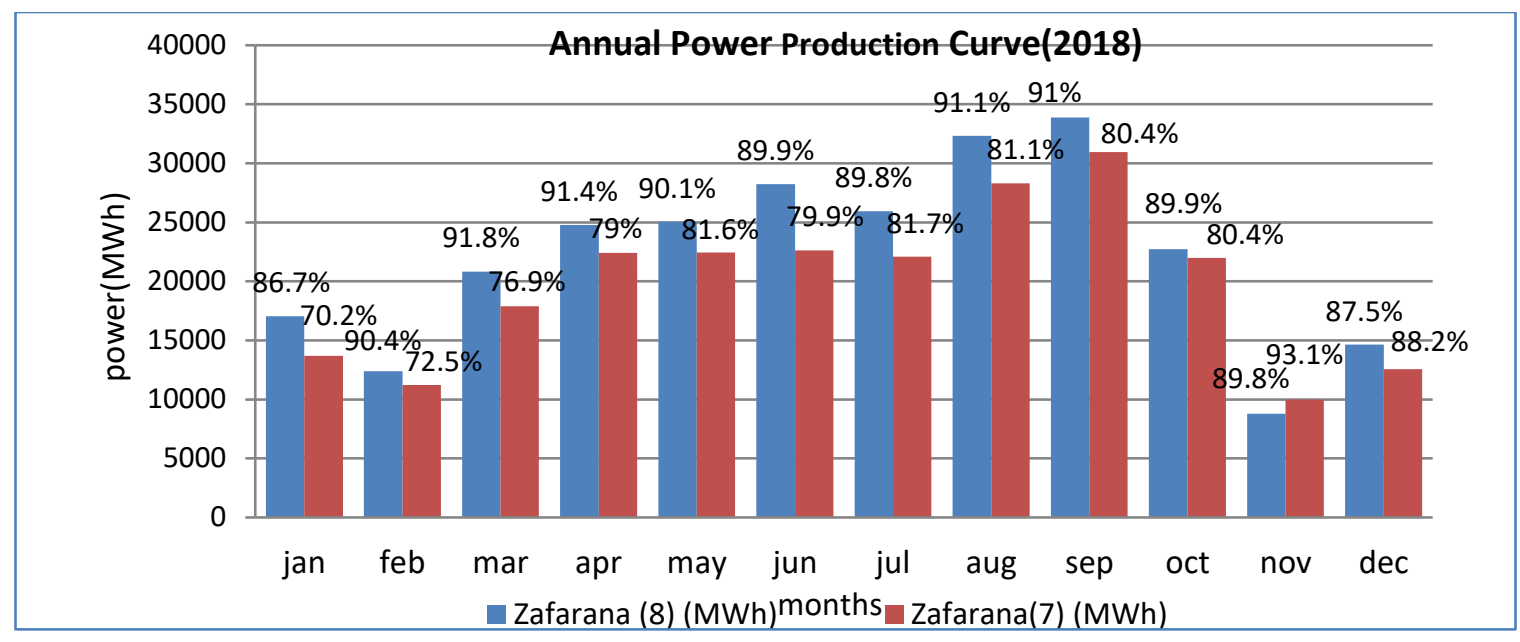

Fig. 4 Power distribution of the two projects in (2018)

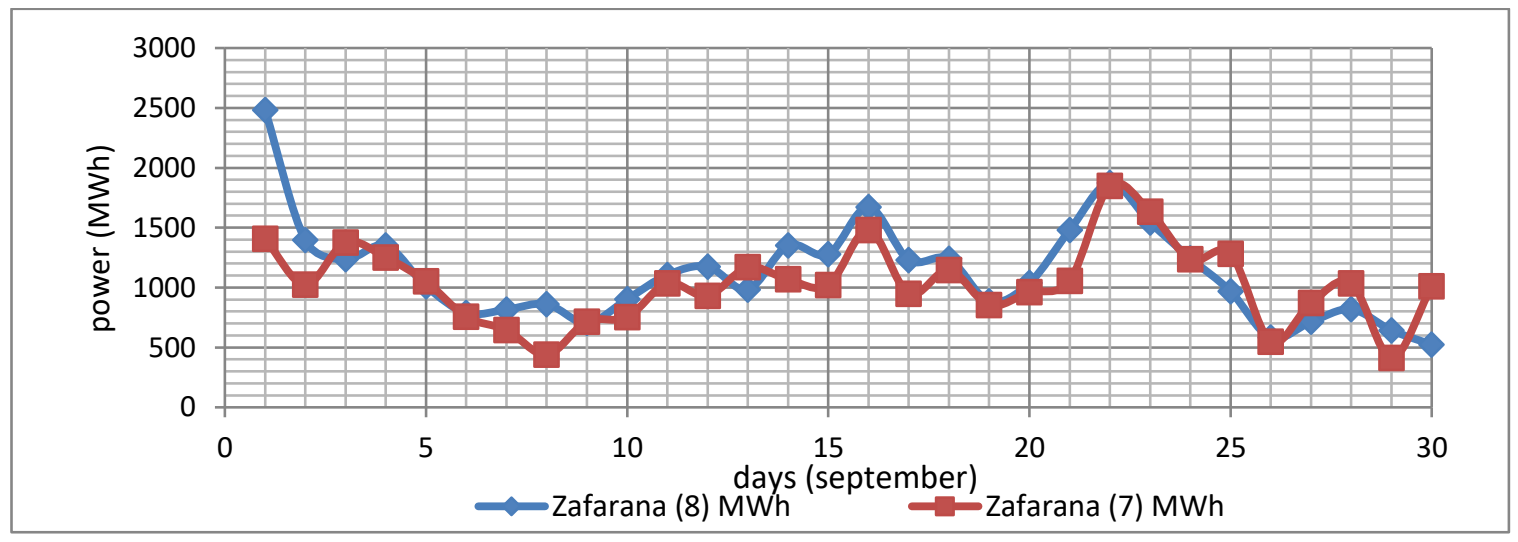

Fig. 8 Power distribution of the two projects in September (2018) 


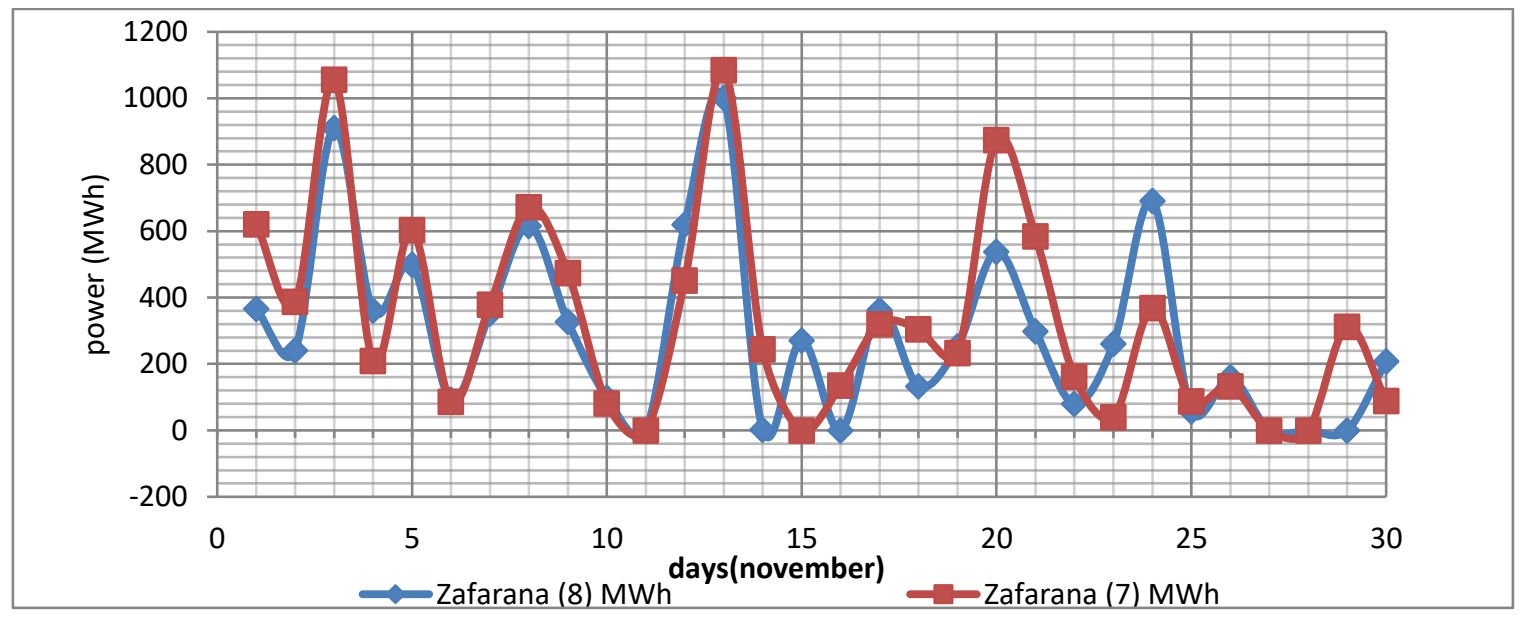

Fig. 9 Power distribution of the two projects in November (2018)

Table 5. Power distributions of the two projects in 2019

\begin{tabular}{|c|c|c|c|c|c|c|}
\hline months & $\begin{array}{c}\text { Zafarana(Z8) } \\
\text { (MWh) }\end{array}$ & $\begin{array}{c}\text { zafarana(Z7) } \\
\text { (MWh) }\end{array}$ & $\begin{array}{c}\text { availability } \\
(\mathrm{Z7}) \%\end{array}$ & $\begin{array}{c}\text { Availability } \\
(\mathrm{Z}) \%\end{array}$ & $\begin{array}{c}\text { Aver. Wind } \\
\text { speed }(\mathrm{m} / \mathrm{s})\end{array}$ & $\begin{array}{c}\text { Aver. Wind } \\
\text { speed (m/s) }\end{array}$ \\
\hline jan & 13840 & 15895 & 86.30 & 84.30 & 6.05 & 5.8 \\
\hline feb & 12477 & 12608 & 90.1 & 89.50 & 5.7 & 6 \\
\hline mar & 22408 & 17204 & 87.3 & 92.10 & 6.8 & 6.2 \\
\hline apr & 19507 & 15176 & 88.60 & 91.70 & 6.64 & 6.4 \\
\hline may & 27826 & 24142 & 90.0 & 90.27 & 7.3 & 7 \\
\hline jun & 28511 & 24980 & 90.80 & 93.30 & 8.4 & 8.7 \\
\hline jul & 26983 & 24608 & 89.80 & 89.70 & 8.57 & 8.67 \\
\hline aug & 23137 & 21367 & 91.20 & 93.40 & 7.41 & 8.2 \\
\hline
\end{tabular}

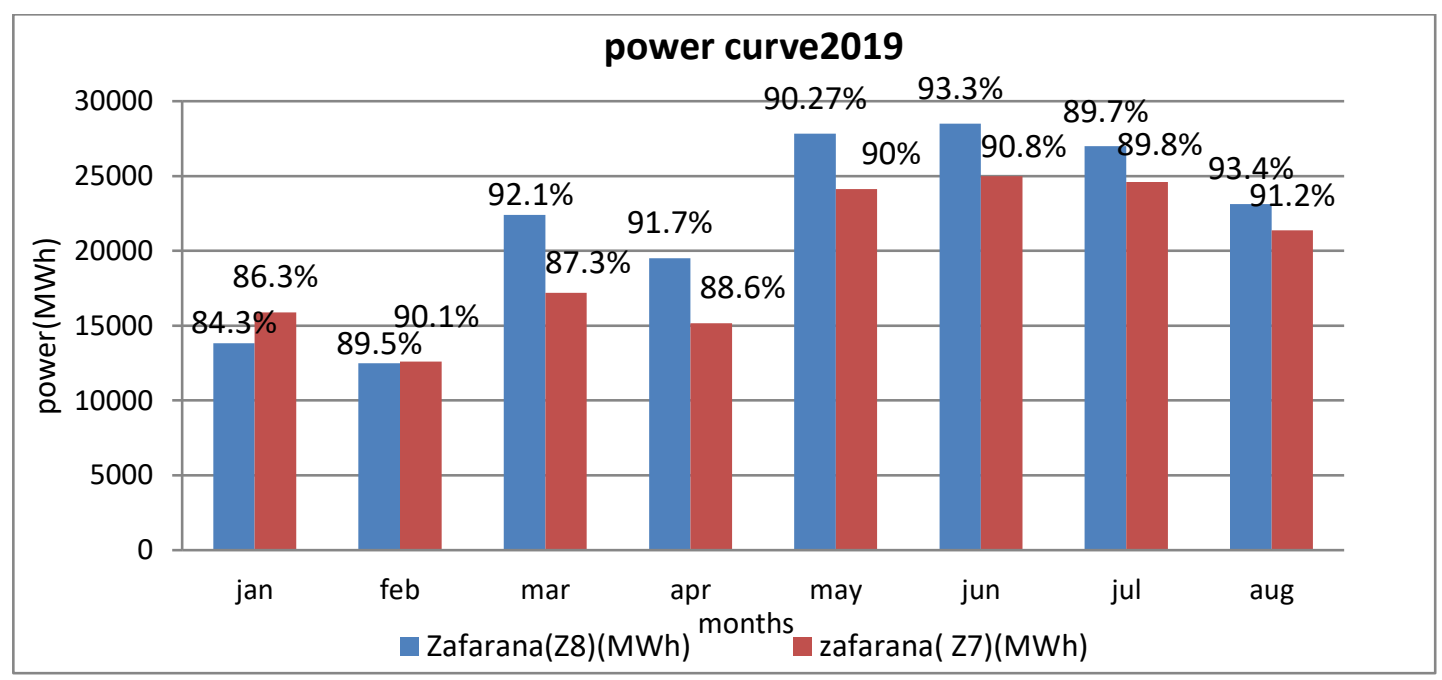

Fig. 5 Power distribution in 2019 


\section{Conclusions}

Based on the data obtained from SCADA Systems at Egypt, Zafarana Wind farm, it turns out the effect of the following conditions on the power

A-the climate (wind speed, landscape)

B-the human factor

C-Spare parts availability

\section{ACKNOWLEDGMENT}

This work is funded by the New and Renewable Energy Authority, Egypt

\section{REFERENCES}

[1]- Boyle, G. (2004). Renewable energy. Renewable Energy, by Edited by Godfrey Boyle, pp. 456. Oxford University Press, May 2004. ISBN-10: 0199261784. ISBN13: $9780199261789,456$.

[2]- Hudson, R. M. (2008). Control system for doubly fed induction generator: Google Patents.

[3]- Ragheb, M. (2012). Wind shear, roughness classes and turbine energy production.

Stavrakakis, G. (2012). 2.10 Electrical Parts of Wind Turbines. 